\title{
Composition and Refractory Properties of Mixtures of Moroccan Silica-Alumina Geomaterials and Alumina
}

\author{
Chaouki Sadik $^{1 *}$, Iz-Edinne El Amrani ${ }^{2}$, Abderahman Albizane ${ }^{1}$ \\ ${ }^{1}$ Department of Chemistry, Faculty of Science and Technology, University Hassan II Mohammedia, Casablanca, Morocco; \\ ${ }^{2}$ Department of Earth Sciences, Geo-Materials and Geo-Environment Team (Geo M\&E), Scientific Institute, University Mohammed \\ V Agdal, Rabat, Morocco. \\ Email: *schawki37@gmail.com
}

Received February $21^{\text {st }}, 2013$; revised March 22 ${ }^{\text {nd }}, 2013$; accepted April $2^{\text {nd }}, 2013$

Copyright (C) 2013 Chaouki Sadik et al. This is an open access article distributed under the Creative Commons Attribution License, which permits unrestricted use, distribution, and reproduction in any medium, provided the original work is properly cited.

\begin{abstract}
Five mixtures (M1 to M5) of silica-alumina geomaterials and two varieties of alumina ( $A_{P}$ and $\left.A_{R}\right)$ were used for the elaboration of mullite refractory materials between $1500^{\circ} \mathrm{C}$ and $1600^{\circ} \mathrm{C}$. An X-ray diffraction (XRD) analysis showed that the refractory samples are composed of mullite, corundum and silica. The length of the mullite crystals was measured by a method of image analysis of scanning electron microscopy (SEM). Chemical and mechanical properties of these materials were investigated and correlated with their microstructure. Resistance towards Acid Attack test showed that the refractory samples present good resistance, as well as, the alumina powder $A_{R}$ obtained from waste of silica-alumina bricks proves to be efficient for an eventual use.
\end{abstract}

Keywords: Clay; Silica-Alumina; Mullite Refractory; Mechanical Properties

\section{Introduction}

Refractory materials most commonly used for lining furnace walls are synthesized mainly from silica-alumina geomaterials [1-3]. The control of the quality of refractory demands a wide knowledge in various scientific fields (geology, mineralogy, geochemistry, thermodynamics, mechanics $\cdots)$. In fact, the production chain has a number of steps (choice of raw material, mixture preparation, drying, pressing, firing $\cdots$ ) requiring perfect mastery and which the slightest error or neglect of any parameter results in failures in the final refractory product quality.

Many research studies have been conducted, until now, on mullite $\left(3 \mathrm{Al}_{2} \mathrm{O}_{3}-2 \mathrm{SiO}_{2}\right)$ as a mineral phase with many properties: low thermal expansion and conductivity, excellent creep resistance, high temperature strength, and good chemical stability [4]. These studies have focused on their synthesis methods, their phase equilibrium, their microstructures and their thermo-mechanical properties $[4,5]$.

Different types of mullite can be synthesized according to the nature of the raw materials and the used process [6-11]. The application fields of mullite are multiple

\footnotetext{
"Corresponding author.
}

and depend on the properties of each type. In fact, the performance of a refractory (good resistance of heat and thermal shock) is directly related to its texture and its richness in mullite.

Kaolinitic clays are used to make fire-clays and silicaclays refractory materials. Alumina-silica (cyanide, sillimanite and andalousite) and alumina hydrates (boehmite, diaspore, gibbsite) are the main raw materials for the alumina refractory products. Silica in a form of quartzite, sand or aggregates is used for the silica based refractory materials elaboration [1]. Kaolin has the advantage to be easily accessible and not expensive in natural open work seams [8]. The main mineral constituent of the kaolin is the kaolinite. Its theoretical formula is $\mathrm{Al}_{2} \mathrm{O}_{3} \cdot 2 \mathrm{SiO}_{2} \cdot 2 \mathrm{H}_{2} \mathrm{O}$. The kaolinite is a phyllosilicate composed of a silica tetrahedral layer $\left[\mathrm{Si}_{2} \mathrm{O}_{5}\right]^{2-}$ and an octahedral hydroxide layer $\left[\mathrm{Al}_{2}(\mathrm{OH})_{4}\right]^{2+}$. Kaolinite firing induces numerous complex structural and microstructural transformations leading to the formation of mullite and a silica phase, mainly in a vitreous form, according to the following reaction [1]:

$3\left(\mathrm{Al}_{2} \mathrm{O}_{3} \cdot 2 \mathrm{SiO}_{2} \cdot 2 \mathrm{H}_{2} \mathrm{O}\right)=3 \mathrm{Al}_{2} \mathrm{O}_{3} \cdot 2 \mathrm{SiO}_{2}+4 \mathrm{SiO}_{2}+6 \mathrm{H}_{2} \mathrm{O}$

The aim of this study is to synthesize the mullite by high temperature treatment of local Moroccan silicaalumina geomaterials (kaolin clay, red clay and silica 
sand), as well as two varieties of alumina, pure alumina $\left(A_{p}\right)$ and alumina $\left(A_{R}\right)$ recovered from waste of silicaalumina refractory bricks.

\section{Materials and Experimental Procedure}

The samples studied were made from a mixture selected among various compositions of kaolin clay, red clay and silica sand $[8,12]$. The clays were used in crude forms.

Kaolin clay $(\operatorname{ArgK})$ is resulting from hydrothermal alteration of alkali granite of Oulmès, located in the center of the Moroccan Meseta. This alteration caused the kaolinization of alkali-feldspar of the granitic rock and gives an aluminous friable material (Table 1), rich in kaolin clay with an appreciable quantity of quartz, flakes of muscovite, and chloritized biotite (Table 2). Red Clay (ArgS) is a very fine-grained silt of lower Cretaceous age, rich in clay minerals and poor in carbonates (Tables 1 and 2). Very large outcrops of these clay deposits exist in the region of Safi. Clays of this region are intensely exploited by the industrial ceramists for the manufacture of bricks and tiles. Silica Sand (SabM) used in this study comes from an artisanal quarry, located at $3 \mathrm{~km}$ SE of the Mechraa Hammadi Dam. The sands appear as a thin layer of a white-pink and friable rock, belonging to the serie of limestone of the upper Jurassic (130 Ma).

The very fine alumina powders " $\mathrm{A}_{\mathrm{P}}$ " commercialized by the industrial unit "Super Cerame" have characteristics and specific functions in terms of rheology, mechanical and chemical strength and refractoriness. Our choice was mainly guided by its high purity of alumina $(99.9 \%)$. An $\mathrm{X}$-ray diffraction (XRD) analysis showed that this powder is mainly composed of Corundum (Figure 1). The contamination level of silica-alumina refractory materials used as coatings in kilns in the ceramics industry is low. It is for this reason that firebrick having undergone three years of use as a coating in a kiln was finely milled to obtain a white powder " $\mathrm{A}_{\mathrm{R}}$ ", and that contains $71.14 \%$ of alumina. Mineralogical analysis of this powder shows that it consists mainly of mullite (Figure 1).

X-Ray Diffraction (XRD) analyses of the two materials (ArgK and ArgS) were used to determine the nature of their clay minerals and semi-quantitative composition (Table 2). The Table also inserts the carbonate contents, measured using Bernard's calcimeter. The mineralogical composition of ArgK consists mainly on kaolinite and small quantities of quartz and illite. The following mineralogical phases were identified for the red clay (ArgS): illite as the principal mineral, with kaolinite and quartz. Other secondary minerals phases found in this clay are hematite and dolomite (Figure 1). Rational mineralogical composition analysis is showed in Table 2.

To attain the objectives of this research, we proceed in two steps.

\subsection{Preparation of Mixtures}

We prepare five mixtures (M1 to M5) that allowed obtaining ceramics resisting to a temperature exceeding $1500^{\circ} \mathrm{C}$, which we can already considered as refractories (Table 3).

\subsection{Preparation of Refractory Bricks and Crucibles}

A quantity of 100 grams is prepared for each mixture (M1 to M5) according to the proportions indicated in Table 3. Each mixture is passed in planetary mill (mean grain size $<100 \mu \mathrm{m}$ ). After $10 \%$ moistening, the powders are shaped by uniaxial pressure at $30 \mathrm{MPa}$ into molds of $100 \times 50 \mathrm{~mm}^{2}$. The obtained samples are submitted to a drying $110^{\circ} \mathrm{C} / 24 \mathrm{~h}$ and calcination at $600^{\circ} \mathrm{C}$ during $1 \mathrm{~h}$. Then they are fired at high temperatures up to $1600^{\circ} \mathrm{C}$ $\left(5^{\circ} \mathrm{C} / \mathrm{mn}\right)$ in an oven (Thermolyne 46,200) [13]. During their firing, the briquettes are subjected to various tests to determine their physic-mechanical properties: thermal sh-

Table 1. Chemical compositions by XRF of the geomaterials used in this study (wt\%) (Chemical analysis were performed in laboratories UATRS, CNRST “Morocco" in 2012).

\begin{tabular}{|c|c|c|c|c|c|c|c|c|c|c|c|}
\hline & $\mathrm{SiO}_{2}$ & $\mathrm{TiO}$ & $\mathrm{Al}_{2} \mathrm{O}_{3}$ & $\mathrm{Fe}_{2} \mathrm{O}_{3}$ & $\mathrm{MgO}$ & $\mathrm{CaO}$ & $\mathrm{Na}_{2} \mathrm{O}$ & $\mathrm{K}_{2} \mathrm{O}$ & $\mathrm{P}_{2} \mathrm{O}_{5}$ & PAF & Total \\
\hline $\operatorname{ArgK}$ & 57.20 & 0.08 & 29.40 & 4.50 & 0.65 & 0.26 & 1.55 & 3.08 & 0.00 & 3.28 & 100.0 \\
\hline $\operatorname{ArgS}$ & 51.60 & 1.06 & 19,20 & 9.00 & 5.36 & 0.90 & 0.58 & 3.89 & 0.23 & 8.16 & 99.98 \\
\hline SabM & 96.06 & 0.15 & 2.22 & 0.51 & 0.17 & 0.09 & 0.06 & 0.20 & 0.02 & 0.49 & 99.97 \\
\hline
\end{tabular}

Table 2. Semi-quantitative analysis of clay mineral and carbonate content (Mineralogical analysis were performed in laboratories UATRS, CNRST “Morocco" in 2012).

\begin{tabular}{cccccc}
\hline Materials & Kaolinite & Illite & Quartz & Dolomite & Hematite \\
\hline ArgK & $44.00 \%$ & $25.67 \%$ & $30.32 \%$ & - & 2.62 \\
ArgS & $21.35 \%$ & $39.65 \%$ & 25 & 10 & 2.14 \\
\hline
\end{tabular}



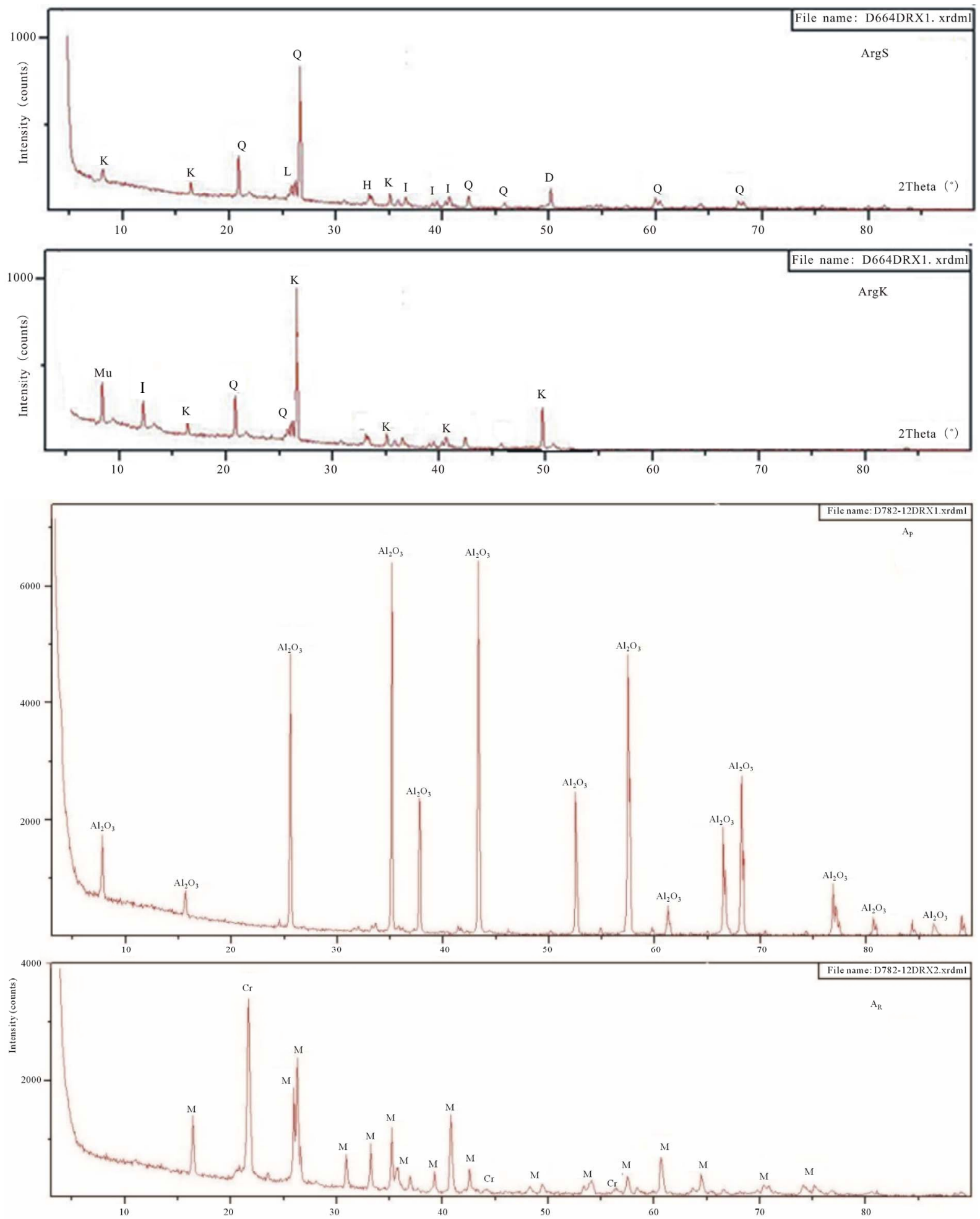

Figure 1. XRD patterns of materials. (K: Kaolinite, I: Illite, H: Hematite, Q: Quartz, D: Dolomite, Mu: Muscovite, M: Mullite, Cr: Cristobalite).

rinkage, porosity and flexural strength. The tests were performed according to the procedures recommended by ASTM $[14,15]$.

Starting from the knowledge of the laboratory of Geo- materials and Geo-Environment in the field of ceramics, we have elaborated refractory crucibles specifically adapted to our needs, which can solve the problems found in laboratory experiments. The studied mixtures are 
Table 3. Composition of mixtures from different types of geomaterials.

\begin{tabular}{cccccc}
\hline & ArgK & ArgS & SabM & $\mathrm{A}_{\mathrm{P}}$ & $\mathrm{A}_{\mathrm{R}}$ \\
\hline M1 & 30 & 10 & 10 & 25 & 25 \\
M2 & 40 & 15 & 5 & - & 40 \\
M3 & 50 & - & 20 & 30 & - \\
M4 & - & - & 40 & 60 & - \\
M5 & - & - & 40 & - & 60 \\
\hline
\end{tabular}

moistened until obtaining homogeneous paste clay. The shaping is done by pressing between two aluminum molds cylindrical format $(10.1 \mathrm{~cm}$ diameter $)$ with perfectly smooth walls, which allows applying a controlled force at the shaping (Figure 2).

\section{Results and Discussions}

\subsection{Physical Properties}

The physical characteristics of the five samples are showed in Figure 3 and Table 4. Several studies carried out on refractory clay materials $[1-3,8,9]$ showed that the sintered brick characteristics are influenced by the mineralogical composition of clays and the firing temperature. The firing temperature of brick made using the clays also influences properties, with higher temperatures enhancing densification by the formation of a liquid phase. The liquid phase is formed by reactions that occur in the presence of free silica, alumina and alkaline, in accordance with the ternary $\mathrm{SiO}_{2}-\mathrm{Al}_{2} \mathrm{O}_{3}-\mathrm{R}_{2} \mathrm{O}$ system [2]. The used clays are known for their high plasticity, which allows the introduction of a considerable quantity of silica sand to reduce the heating shrinkage and to ensure dimensional stability during thermal treatments. The incorporation of red clay in the mixture enables adjustment of the physical properties of the fired material.

Refractoriness of a material is strongly dependent on microstructural parameters such as grain size and shape, the relative volume of solid and vitreous phases, the viscosity of the vitreous phase, and sample porosity [2]. Refractoriness can be evaluated by examining the evolution of the morphology of test samples with increasing temperature under their own weight (without any other load). Refractoriness in this paper is defined as the temperature corresponding to the moment when a material begins to lose its shape (melting point). The samples tested here maintained their shape without undergoing any deformation up to $1600^{\circ} \mathrm{C}$. They retain their original characteristics: no cracks, no deformation, no color change, especially a very low shrinkage appears at the end of the thermal cycle.

Table 4 gives the values of the flexural strength of the samples. The briquette M2 and M3 significantly more silica-alumina, have a greater flexural strength compared with others. The substitution of $60 \%$ of pure alumina

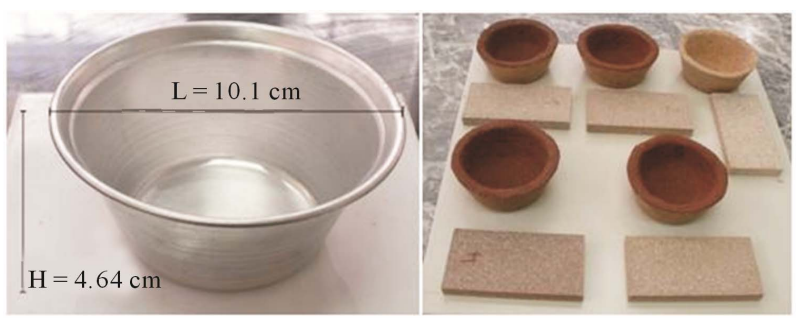

Figure 2. Image of the used mold and elaborated refractory crucibles.
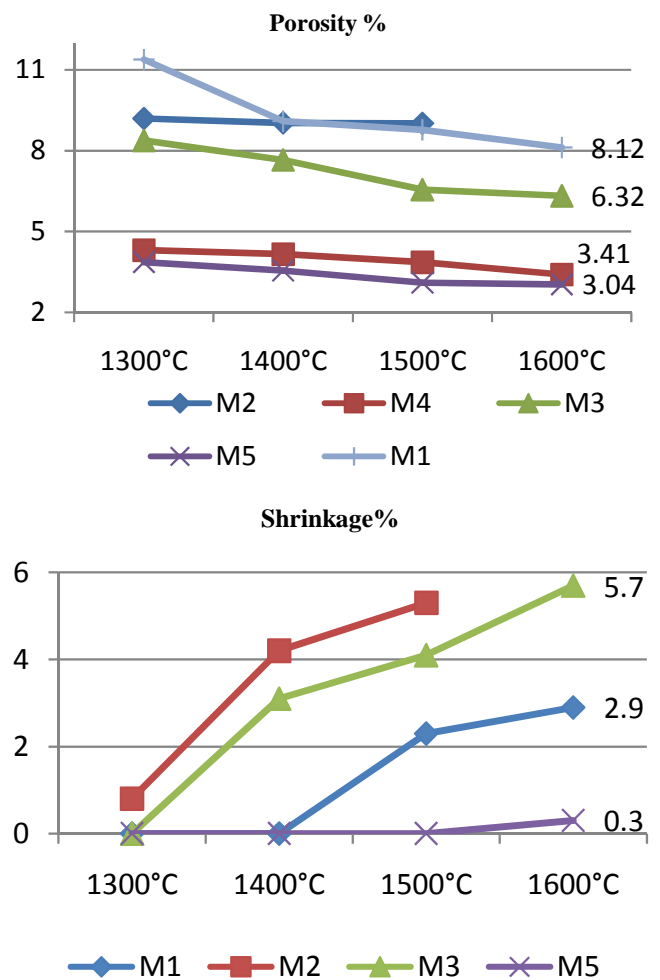

Figure 3. Evolution of porosity and shrinkage from $1300^{\circ} \mathrm{C}$ to $1600^{\circ} \mathrm{C}$.

Table 4. Flexural strength of samples fired at $1500^{\circ} \mathrm{C}$.

\begin{tabular}{cc}
\hline Samples & Flexural strength (MPa) \\
\hline M1 & 66.54 \\
M2 & 71.41 \\
M3 & 70.36 \\
M4 & 41.82 \\
M5 & 55.87 \\
\hline
\end{tabular}

powder $\left(\mathrm{P}_{\mathrm{A}}\right)$ in the briquette $\mathrm{M} 4$ by the recovery alumina $\left(A_{R}\right)$ in the mixture M5 allows increasing the flexural strength of 41.82 to $55.87 \mathrm{MPa}$.

\subsection{Mineralogical Characteristics}

The main crystalline phases identified by XRD after samples were fired at $1600^{\circ} \mathrm{C}$ were mullite, Corundum and cristobalite (Figure 4). Spectra show the presence of 
corundum in the mixtures M1 and M3 (presence of pure alumina powder in the starting mixtures). This phase disappears in the mixture M2. The characteristic diffraction peaks of cristobalite are clear and persist up to $1600^{\circ} \mathrm{C}$.

The SEM micrograph of Figure 5 clearly shows the mullite phase identified by its needle like shape. The briquette M2 shows a homogeneous microstructure and especially richness in very fine needles of mullite. These images show the number and shape of the crystals of mullite synthesized according to the nature of the sample. An EDX analysis shows that the mullite doesn't contain foreign inclusions (Figure 6).

The length of mullite crystals was measured by a method of image analysis of scanning electron micros-
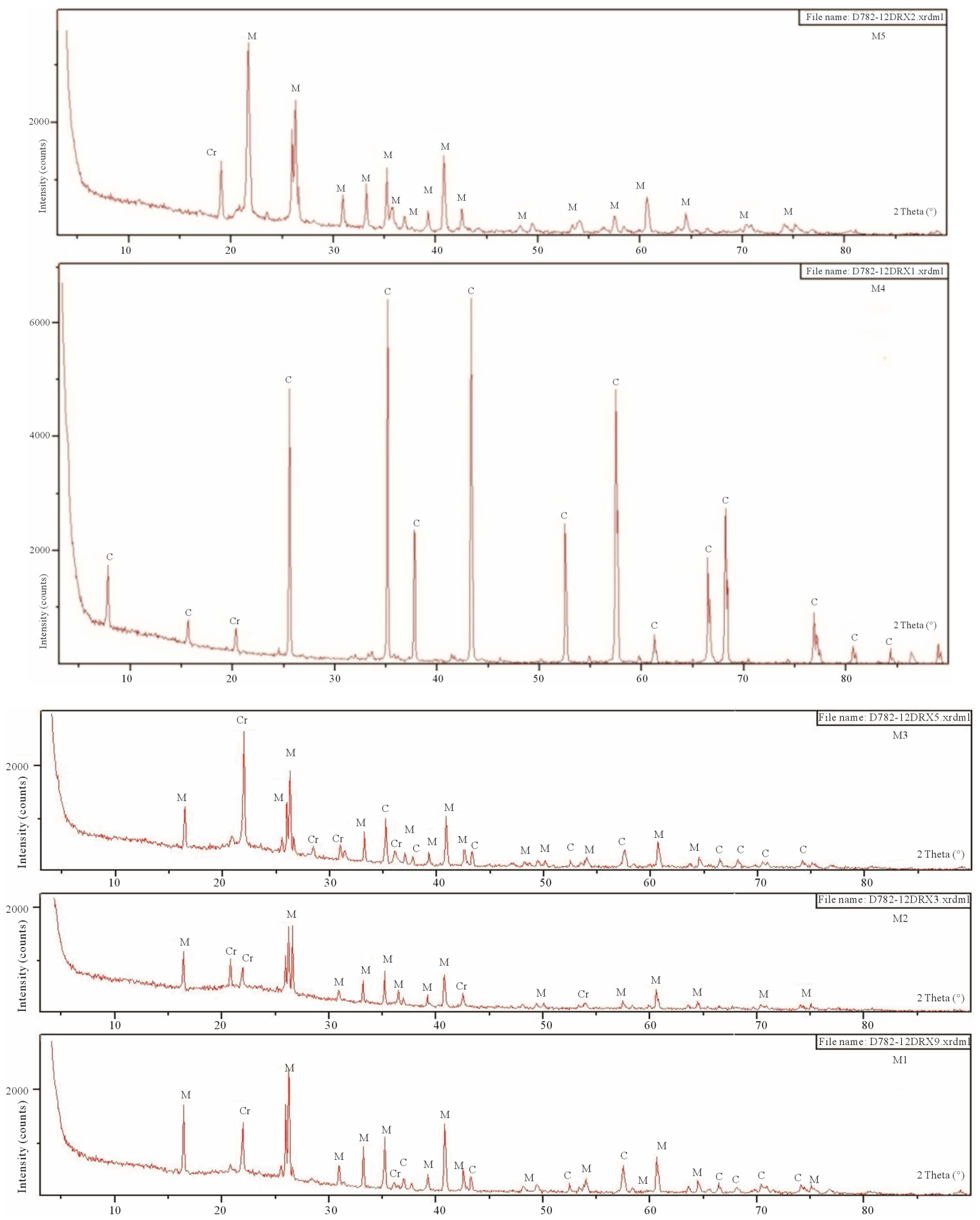

Figure 4. XRD samples of M1, M2, M3, M4 and M5 fired at $1600^{\circ} \mathrm{C}$ (M: Mullite, C: Corundum, Cr: Cristobalite). 


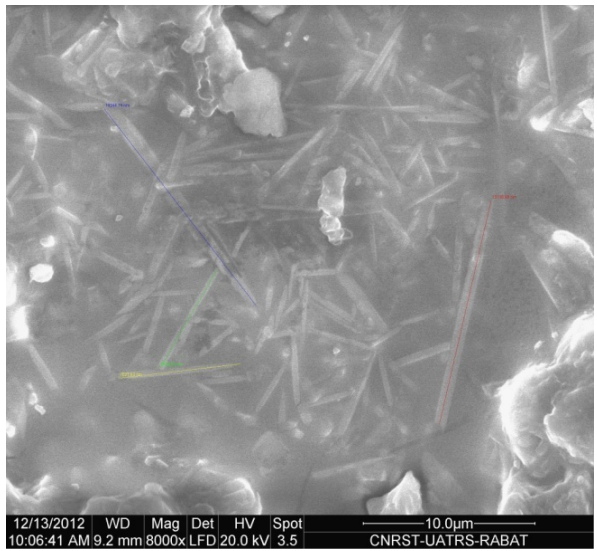

M1

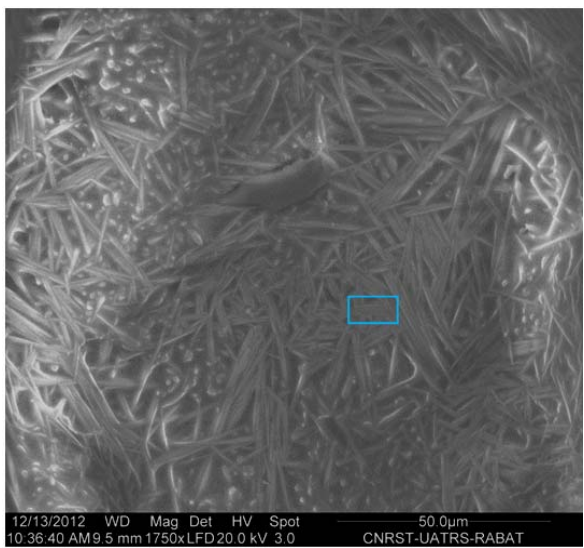

M2

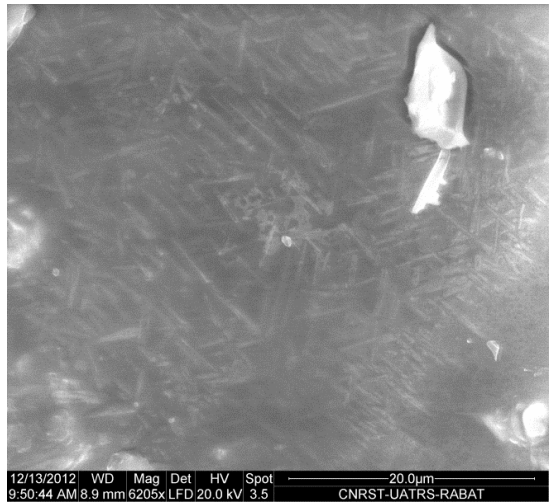

M3

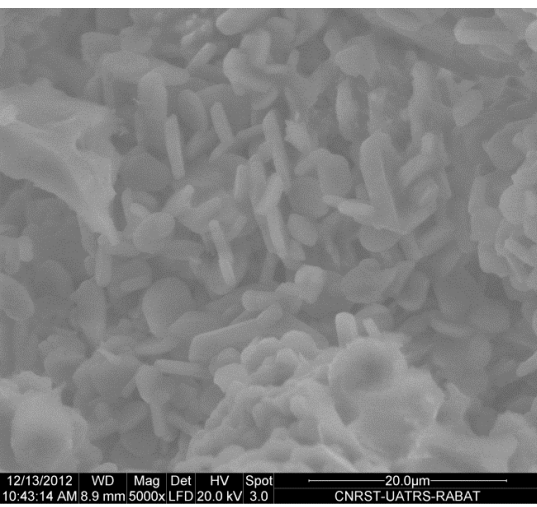

M4

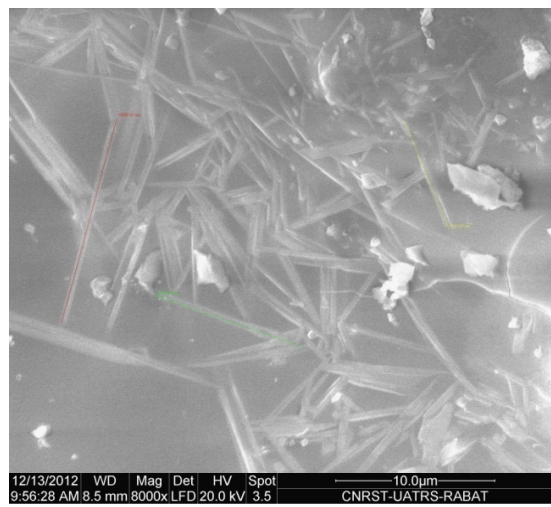

M5

Figure 5. SEM microphotography of samples fired at $1600^{\circ} \mathrm{C}$.

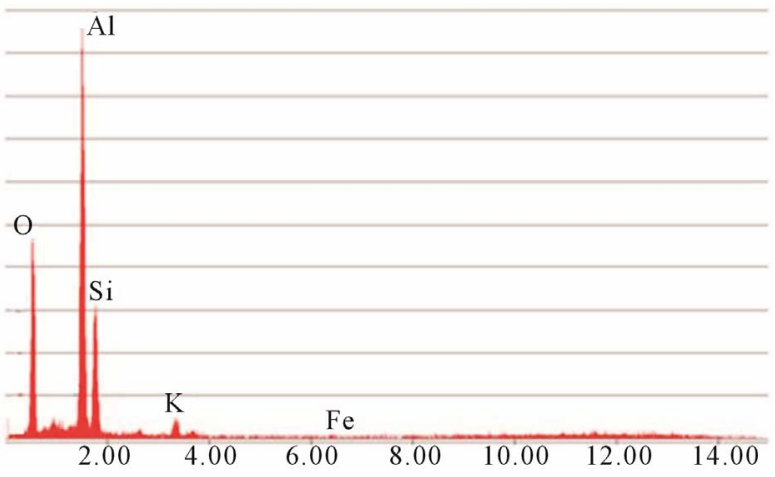

Figure 6. EDX analysis of the square area in Figure 5.

copy (Figure 7). However, there are variations in the size of the mullite to the same sample, which is due to local fluctuations of composition [16]. Figure 7 shows that the length distributions are relatively homogeneous and tightened around an average value for the two samples M1 and M2. There was an increase in the length of mullite for sample M2 [20 - 25 microns] compared to others. Simultaneously, the average width remains constant for the three samples $(0.5$ to $1 \mu \mathrm{m})$. This confirms the existence of a growth phenomenon preferred in the direction [001] [16].

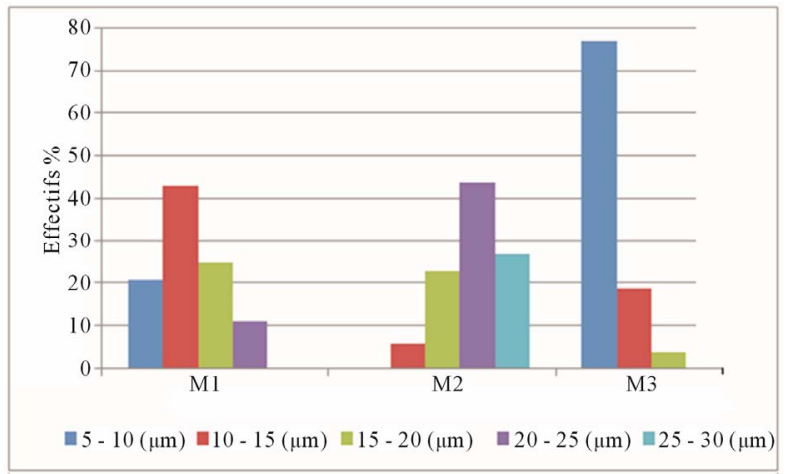

Figure 7. Average length of mullite crystal.

\subsection{Thermal Behavior}

As shown in Figure 8, the obtained curves are typical of materials undergoing microstructural transformations inducing nonlinear and irreversible effects. Their forms presented above are typical of those obtained with materials containing clay minerals [17].

Sintering of aluminosilicate phases which causes shrinkage in the matrix is more important for M3 as M1 and M2. This can be explained by the content of alumina in the initial mixtures. Indeed, the material M3 has the 


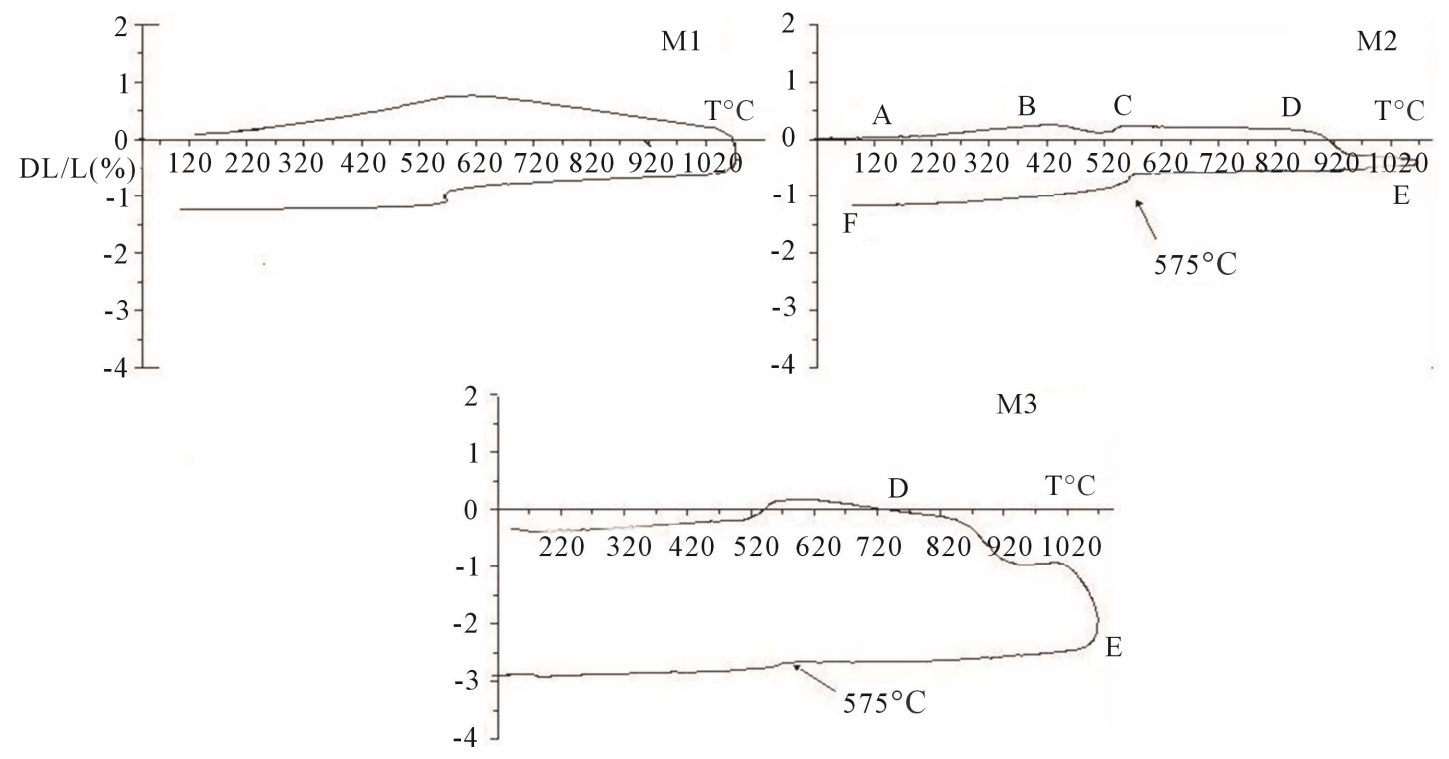

Figure 8. Thermal expansion measured from room temperature to $1100^{\circ} \mathrm{C}$.

lowest quantity of alumina (30\%) and thus undergoes the largest shrinkage $\left(3 \%\right.$ at $\left.1100^{\circ} \mathrm{C}\right)$. The total shrinkage amplitude for $\mathrm{M} 1$ and $\mathrm{M} 2$ is low: about $1.2 \%$ at $1100^{\circ} \mathrm{C}$. During cooling, the shrinkage is linear up to room temperature. The reversible transformation of quartz $\alpha \rightarrow \beta$ for the three materials is observed at $575^{\circ} \mathrm{C}$. For samples M4 and M5, these two materials have given respectively $0.0 \%$ and $0.3 \%$ of thermal shrinkage at $1600^{\circ} \mathrm{C}$. They both do not undergo large dimensional changes due to their high alumina content, unlike mixtures M1, M2 and M3 which have varying amounts in geomaterials susceptible of high dimensional variations.

\subsection{Resistance towards Acid Attack}

The resistance towards sulfuric acid was checked according to NF EN 993-16 standards dealing with dense shaped refractory products [18]. First, the refractory material was ground to a mesh size comprised between 63 and $80 \mu \mathrm{m}$, and then dried. A mass $\mathrm{m}_{\mathrm{i}}$ of this material was then treated in a boiling solution of concentrated sulfuric acid $(18 \mathrm{~N})$. The slurry was rinsed, filtered, dried and the obtained powder was weighted (final mass $\mathrm{m}_{\mathrm{f}}$ ). The relative mass reduction after acid treatment is reported in Table 5.

Table 5 presents a comparison of the acid resistance of elaborated products. One of the three elaborated refractories $\mathrm{M} 2$, which is in fact, the richest one of mullite $(40 \%$ of $A_{R}$ in the starting materials), proves to be the most efficient one. It exhibited better resistance against acid compared to M1 and M3.

\section{Conclusions}

Silica-alumina refractory materials made from such as
Table 5. The relative mass reduction for samples.

\begin{tabular}{cc}
\hline Samples & The relative mass reduction $(\%)$ \\
\hline M1 & 2.3 \\
M2 & 1.2 \\
M3 & 2.9 \\
M4 & 0.5 \\
M5 & 0.2 \\
\hline
\end{tabular}

kaolin clays, red clay and silica sand are widely used in the manufacture of ceramic products (as kiln furniture and bricks). Because the use of these materials is limited at high temperature, knowledge of their thermo-mechanical and deformation properties in fired refractory materials is necessary. Thus, mechanical tests related to flexural strength were carried at $1500^{\circ} \mathrm{C}$, as well as a study of microstructure changes occurring in these compositions. From these studies, the following conclusions were drawn:

- The refractory materials contain mullite, corundum and cristobalite

- Very good dimensional stability is obtained upon firing

- Good mechanical characteristics and chemical resistance to acid are obtained

- Dilatometric tests show a slight and regular variation of the thermal shrinkage/expansion between $100^{\circ} \mathrm{C}$ and $1100^{\circ} \mathrm{C}$, which helps to provide a good thermal shock resistance to the material

- Alumina powder $A_{R}$ obtained from waste of silica-alumina refractory bricks proves to be efficient for an eventual use.

On the other hand, the results of this study have a double economic interest: it contributes to the valorization of 
Moroccan geomaterials and leads to the local synthesis of refractories, where the national need is mainly imported from abroad.

\section{Acknowledgements}

This study was conducted in the laboratory of Geomaterials and Geoenvironment (Geo M\&E) of the Scientific Institute (University Mohammed V-Agdal, Rabat, Morocco). The authors acknowledge support from National Center for Scientific and Technical Research (CNRST) (research unite URAC 46) and Hassan II Academy for Sciences and Techniques (Project V2GV). Authors would like to thank "Super Cerame" Company for supplying the alumina powder and waste of refractory bricks.

\section{REFERENCES}

[1] M. Kolli, M. Hamidouche, G. Fantozzi and J. Chevalier, "Elaboration and Characterization of a Refractory Based on Algerian Kaolin," Ceramics International, Vol. 33, No. 8, 2007, pp. 1435-1443. doi:10.1016/j.ceramint.2006.06.009

[2] B. Amrane, E. Ouedraogo, B. Mamen, S. Djaknoun and N. Mesrati, "Experimental Study of the Thermo-Mechanical Behaviour of Alumina-Silicate Refractory Materials Based on a Mixture of Algerian Kaolinitic Clays," $\mathrm{Ce}$ ramics International, Vol. 37, No. 8, 2011, pp. 32173227. doi:10.1016/j.ceramint.2011.05.095

[3] M. A. Sainz, F. J. Serrano, J. M. Amigo, J. Bastida and A. Caballero, "XRD Microstructural Analysis of Mullite Obtained from Kaolinite-Alumina Mixtures," Journal of the European Ceramic Society, Vol. 20, No. 4, 2000, pp. 403-412. doi:10.1016/S0955-2219(99)00183-1

[4] J. Anggono, "Mullite Ceramics: Its Properties, Structure and Synthesis," Jurnal Teknik Mesin, Vol. 7, No. 1, 2005, pp. $1-10$.

[5] J. Poirier, "Les Céramiques Réfractaires, de l'Elaboration aux Propriétés d'Emploi," Verres, Céramiques et Composites, Vol. 1, 2011, pp. 28-42.

[6] M. A. Sainz, F. J. Serrano, J. Bastidab and A. Caballero, "Microstructural Evolution and Growth of Crystallite Size of Mullite during Thermal Transformation of Kyanite," Journal of the European Ceramic Society, Vol. 17, No. 11, 1997, pp. 1277-1284. doi:10.1016/S0955-2219(96)00231-2

[7] J. A. Santillan, H. B. Ramirez and R. C. Bradt, "Dense Mullite from Attrition Milled Kyanite and $\alpha$-Alumina,"
Journal of Ceramic Processing Research, Vol. 8, No. 1, 2007, pp. 1-11.

[8] C. Sadik, I. El Amrani and A. Albizane, "Silica-Alumina Refractory Synthesis Based on Moroccan Granitic GeoMaterials," Journal of Chemical \& Engineering, Vol. 7, No. 2, 2013 (in press).

[9] F. Sahnoune, M. Chegaar, N. Saheb, P. Goeuriot and F. Valdivieso, "Algerian Kaolinite Used for Mullite Formation App," Clay Science, Vol. 38, No. 3-4, 2008, pp. 304 310. doi:10.1016/j.clay.2007.04.013

[10] M. L. Bouchetou, J. P. Ildefonse, J. Poirier and P. Daniellou, "Mullite Grown from Fired Andalusite Grains: The Role of Impurities and of the High Temperature Liquid Phase on the Kinetics of Mullitization and Consequences on Thermal Shocks Resistance," Ceramics International, Vol. 31, No. 7, 2005, pp. 999-1005. doi:10.1016/j.ceramint.2004.10.015

[11] W. Pannhorts and H. Schneider, "The High-Temperature Transformation of Andalusite $\left(\mathrm{Al}_{2} \mathrm{SiO}_{5}\right)$ into 3/2 Mullite $\left(3 \mathrm{Al}_{2} \mathrm{O}_{3}-2 \mathrm{SiO}_{2}\right)$ and Vitreous Silica $\left(\mathrm{SiO}_{2}\right)$, , Mining Magazine, Vol. 42, No. 322, 1978, pp. 195-198. doi:10.1180/minmag.1978.042.322.05

[12] C. Sadik, I. El Amrani and A. Albizane, "Influence de la Nature Chimique et Minéralogique des Argiles et du Processus de Fabrication sur la Qualité des Carreaux Céramiques," MATEC Web, Conf., Vol. 2, 2012, Article ID: 01016. doi:10.1051/matecconf/20120201016

[13] ASTM C 326-03, "Standard Test Method for Drying and Firing Shrinkages of Ceramic Whiteware Clays, Volume 15-02, Glass and Ceramic," 2006.

[14] ASTM C373-88, "Standard Test Method for Water Absorption, Bulk Density, Apparent Porosity, and Apparent Specific Gravity of Fired White Ware Products, Volume 15-02, Glass and Ceramic,” 2006.

[15] ASTM C674-88, "Standard Test Methods for Flexural Properties of Ceramic White Ware Materials, Volume 15-02, Glass and Ceramic," 2006.

[16] F. G. Bennadji, "Matériaux de mullite à microstructure organisée composés d'assemblages muscovite-kaolinite," Thèse, Faculté des Sciences et Techniques, Groupe d'Etude des Matériaux Hétérogènes. Université de Limoges, Limoges, 2007, p. 141.

[17] N. El Yakoubi, M. Aberkan and M. Ouadia, "Potentialité d'Utilisation d'Argiles Marocaines de Jbel Kharrou Dans l'Industrie Céramique," Comptes Rendus Geoscience, Vol. 338, No. 10, 2006, pp. 693-702. doi:10.1016/j.crte.2006.03.017

[18] BS EN 993-16, "Methods of Test for Dense Shaped ReFractory Products. Determination of Resistance to SulPhuric Acide," 1995. 